\title{
3
}

\section{EL FEDERALISMO EN AUSTRALIA: LA CUESTIÓN DE LAS TRANSFERENCIAS DE FONDOS}

\author{
Rogers Wilkins \\ (University of Sydney y Citigroup)
}

\begin{abstract}
RESUMEN
Se aborda la temática de las transferencias de fondos entre el gobierno federal y los provinciales, señalando aspectos del federalismo australiano. La disparidad entre los estados y el desequilibrio fiscal vertical en Australia son compensados, en parte, con la implementación del criterio de igualdad fiscal, que lleva adelante la Comisión de Subsidios. Con el propósito de lograr equidad en el acceso a bienes y servicios públicos en todo el territorio, a través de procedimientos técnicos, se consideran las capacidades de los estados para recaudar y los costos de las prestaciones y se recomienda un modo de distribución de los fondos. De ese modo, ese sistema fiscal federal permite la convivencia entre estados miembros desiguales. Por último, se señala que la mitad de las transferencias se realizan de acuerdo ese criterio y el resto mediante "fondos condicionados", a través de los cuales el gobierno central define políticas en las provincias.
\end{abstract}

\section{PALABRAS CLAVE:}

transferencias de fondos, desequilibrio fiscal vertical, equidad fiscal.

\section{ABSTRACT}

Pointing out aspects of the Australian federalism, the subject matter on fund transference between the federal government and the provincial ones the vertical fiscal imbalance in Australia are compensated, in part, with the implementation of the fiscal equalization criterion carried out by the Commission of Subsidies. By means of technical procedures and aiming to achieve equity in accessing public properties and services thorughout the territory, the state's capacities to collect and the state's welfare cost are considered while a fund distribution form is recommended. Thereby, such federal fiscal system allows the coexistence among unequal state-members. Lastly, it is mentioned that half of the transferences are made in accordance with such criterion and the rest by "conditioned funds" through which the central state defines politics in the provinces.

\section{KEY WORDS:}

fund transference, vertical fiscal imbalance, fiscal equalization. 